\title{
AZ80マグネシウム合金の高温変形集合組織の形成に及ぼす 初期集合組織の影響
}

\author{
金 卷煦* ·岡安 和人**. 福富 洋志 $* *$
}

Journal of The Japan Institute of Light Metals, Vol. 63, No. 6 (2013), 212-217

(C) 2013 The Japan Institute of Light Metals

\section{Influence of the initial texture on texture formation of high temperature deformation in AZ80 magnesium alloy}

\author{
Kwonhoo KIM*, Kazuto OKAYASU** and Hiroshi FUKUTOMI**
}

The texture formation mechanism during high temperature deformation is investigated on AZ80 magnesium alloy. Three kinds of specimens with different initial textures were machined out from rolled plate having a $\langle 0001\rangle$ texture. Plane strain compression tests were conducted at $723 \mathrm{~K}, 5.0 \times 10^{-2} \mathrm{~s}^{-1}$ and strains ranging from -0.4 to -1.0 . Development of $(0001)\langle 10 \overline{1} 0\rangle$ component is confirmed regardless of the initial texture. It is concluded that the development of $(0001)\langle 10 \overline{1} 0\rangle$ component can be attributed to the grain boundary migration during deformation. Besides $(0001)\langle 10 \overline{1} 0\rangle$ component, several texture components appeared depending on the initial texture.

(Received October 2, 2012 Accepted February 27, 2013)

Keywords: magnesium alloy, texture, plane strain compression

\section{1. 緒言}

固溶体合金を高温で加工すると, 室温での加工とは異なる 集合組織が現れることがある。著者等はこれまで $\mathrm{Al}-\mathrm{Mg}$ 合 金 $^{1), 2)}, \mathrm{Al}-\mathrm{Cu}$ 合金 $^{3)}, \mathrm{Fe}-\mathrm{Si}$ 合金 ${ }^{4)}$ 等を対象に, 単軸圧縮変 形や平面ひずみ圧縮変形を行って集合組織の形成挙動を調 へ，室温で通常観察される変形集合組織が変形の初期に形成 された後ひずみの増大とともに圧縮面が $\{001\}$ となる集合 組織に変化することを見出した。そして，この集合組織変化 が, $\{001\}$ 方位の結晶粒が他方位の結晶粒を消費して成長す ることによることを実験的に確認し，この挙動は，溶質原子 雲囲気の影響によって転位が均一に分布する ${ }^{5 ）}$ ， 蓄積エ ネルギーの結晶方位依存性が高くなることに由来すると考え た ${ }^{1) \sim 4)}$ 。

展伸用マグネシウム合金の AZ31，AZ61そしてAZ80は， 常温での成形性が十分ではないため，素材の成形は高温で行 うのが通常である。高温加工時に集合組織が形成されるとそ の後の加工性に影響が生じる。特に，熱間圧延時に導入され ることのある底面集合組織は，その後の板材の加工性を損な うため, その形成機構の解明が重要な課題となっている。こ れらのマグネシウム合金は固溶体硬化の大きい合金であり, それゆえ，上述のFCCならびにBCC固溶体合金に見出され た機構によって，集合組織が発達している可能性がある。
$\mathrm{Al}-\mathrm{Mg}$ 合金の研究によって, 溶質濃度が高いほど集合組織形 成の特徵が明瞭になることが判明した。そこで, 溶質濃度の 高いAZ80 合金を対象に, 著者らは熱間押出によって〈1010 繊維集合組織が発達した棒材から初期集合組織が異なるよう に切出して試料を作製し, 変形挙動と集合組織の特徵を調べ た。その結果, (1) 底面集合組織は初期集合組織によらず形 成されること，(2) 変形双晶による（0001）方位結晶粒の生 成が底面集合組織の形成に寄与しうること，（3）初期集合組 織の成分の中には大ひずみ変形後にも残存するものがあるこ と,（4）変形後に存在する集合組織成分の方位は，いずれも 変形に対して安定な方位であることなどを見出した6)。しか し, 初期集合組織の種類は 3 種類のみであり, 双晶による底 面方位をもつ結晶粒の生成が困難な場合など, 高温加工後の 集合組織に存在する結晶方位成分を知るためにさらに初期集 合組織を変えた試料について調べる必要が残されていた。そ こで, 本研究では熱間圧延を行って押出加工とは異なる集合 組織を付与した板材を作製し, 先の研究で調べた試料とは初 期集合組織の主成分が異なる試料を 3 種類作製した。これら の試料について, 変形挙動と集合組織の形成挙動を調べると ともに, 前報の結果と比較し, 本合金における高温変形下で の集合組織の形成機構を検討した。

\footnotetext{
*横浜国立大学大学院工学研究院（† 240-8501 神奈川県横浜市保土ヶ谷区常盤台 79-5）〔現在：釜慶大学校工科大学〕。Faculty of Engineering, Graduate School of Yokohama National University (79-5 Tokiwadai, Hodogaya-ku, Yokohama-shi, Kanagawa 240-8501) (Present: College of Engineering, Pukyong National University]. E-mail: mrppeng@pknu.ac.kr

**横浜国立大学大学院工学研究院（横浜市)。Faculty of Engineering, Graduate School of Yokohama National University (Yokohama-shi, Kanagawa).
} 


\section{2. 実 験方法}

本研究での供試母材は市販の AZ80鋳造ビレットである。 母材インゴットから $60 \times 60 \times 40 \mathrm{~mm}$ の直方体を機械加工によ り切出し，圧下率を $30 \%$ として $673 \mathrm{~K} て ゙$ 圧延を行った。Fig. 1は圧延後の集合組織を調べた結果である。圧延面を投影面 とし，測定範囲内の平均極密度を 1 とした等高線で（0001） の極密度分布が示されている。圧延材について報告されてい る(0001) 繊維集合組織の存在が確認できる7)。

集合組織をもつ圧延板から, 切出し方向を変えることに よって優先方位の異なる 3 種類の平面ひずみ圧縮試験片を作 製した。寸法は $10 \times 10 \times 6.7 \mathrm{~mm}$ である。Fig. 2 は試料の幾何学 的特徵を示したもので, 図中の RDは本研究で行った平面ひ ずみ圧縮変形の際の伸長方向である。圧縮面を斜線面で示し てある。前報 ${ }^{5)}$ と区別するため，試料名を D, E , F と呼ぶ。 試料 Dでは圧縮方向, 試料Eでは変形が拘束される方向（平 面ひずみ圧縮試験における TD方向)，そして試料 Fでは伸長 方向（平面ひずみ圧縮試験における RD方向）がそれぞれ

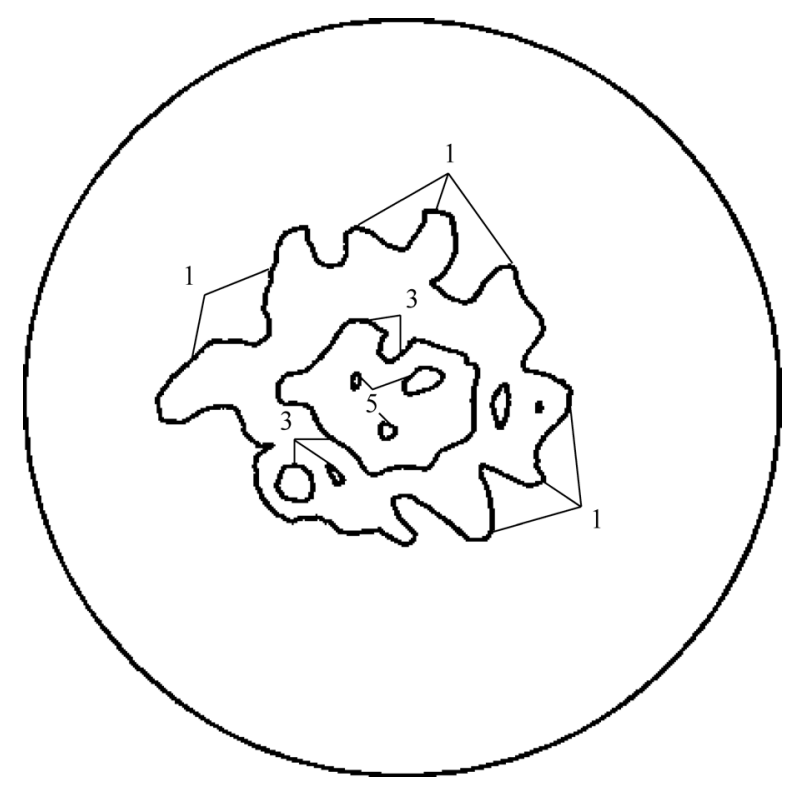

Fig. 1 (0001) pole figure of the AZ80 rolled plate. Pole densities are projected onto the rolling plane. Mean pole density is used as a unit.

(a)

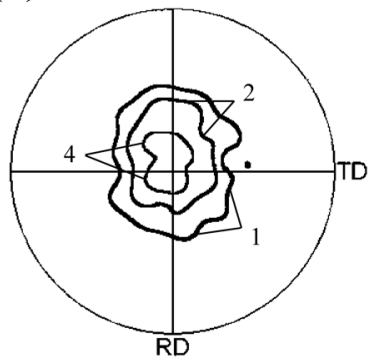

Specimen D (b)

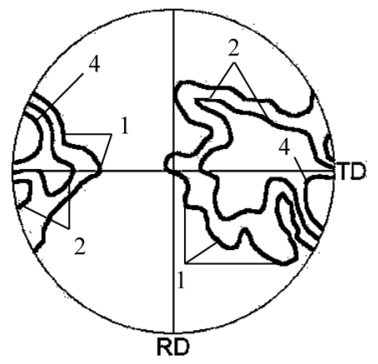

Specimen E
〈0001〉が頻度高く配向した集合組織となっている。いずれ の試料も $723 \mathrm{~K} て ゙ 1 \mathrm{~h}$ 焼なました後試験を行った。

Fig. 3 は試料D，E拈よびFの変形前の結晶方位分布を EBSD測定を基に圧縮面を投影面として描いた（0001）極点 図で示したものである。平面ひずみ圧縮試験は前報と同一 の，温度を $723 \mathrm{~K}$, ひずみ速度を $5.0 \times 10^{-2} \mathrm{~s}^{-1}$ とし，真ひずみ $-0.4 \sim-1.0$ の範囲で行った。試験の概略を Fig. 4に示した。 なお，本報では，ひずみ量を真ひずみの絶対值でこれ以降表 現する。試験後の組織変化を抑えるため, 加工後直ちに試料 を油中に焼入れた。試料の板厚の中心部を機械加工および 研磨により取出した後, エメリーペーパならびにシリカ粒 子 $(0.04 \mu \mathrm{m})$ 懸濁液を用いて表面を仕上げ, 組織観察なら びに集合組織測定を行った。集合組織測定は $\mathrm{CuK} \alpha$ を用いた Schulzの反射法により行った。 $\{10 \overline{1} 0\},\{0001\},\{10 \overline{1} 1\},\{10 \overline{1} 2\}$ および $\{11 \overline{2} 0\}$ の 5 種類の正極点図を計測した。また， 5 種 類の正極点図をもとに, Dahms と Bungeの方法 ${ }^{8)}$ により結晶 方位分布関数 ODF（Orientation Distribution Function）を定め た。ODFをもとに逆極点図を描いて集合組織の主成分なら びに発達度を決定した。X線を用いた計測に加え，EBSD測 定をも行った。EBSD測定は試料に電解研磨を施した上で 行った。

\section{3. 実 験 結 果}

\section{1 変形挙動}

Fig. 5 は 3 種類の試料に対して温度 $723 \mathrm{~K}$, ひずみ速度 5.0 $\times 10^{-2} \mathrm{~s}^{-1}$, ひずみ 1.0 の条件で調べた応力ーひずみ曲線であ る。応力の最大值は異なるが，いずれの試料においても，

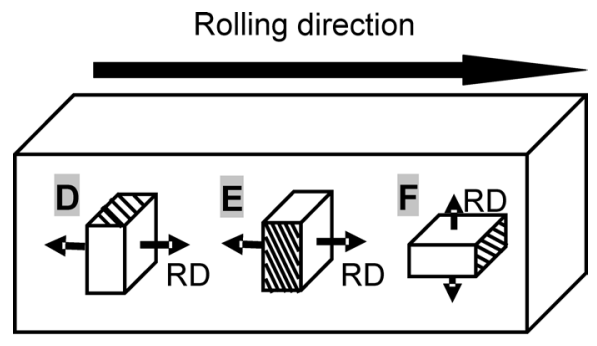

NIN Compression plane

Fig. 2 Preparation of the specimens for plane strain compression.

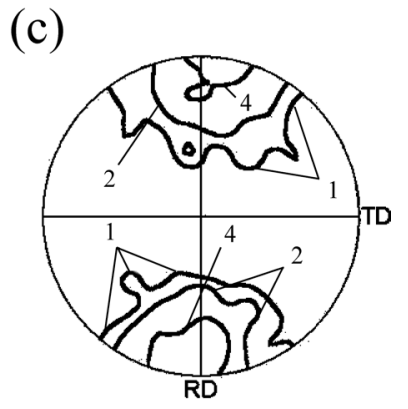

Specimen F

Fig. 3 (0001) pole figures showing the crystallographic characteristics of the specimens. (a), (b) and (c) show the specimens of D, E and F, respectively. Pole densities are projected onto the compression plane. Mean pole density is used as a unit. 
AZ31 や先に報告した初期集合組織の異なる AZ80 と同様に, 加工軟化現象が認められる。D と F はほぼ同一の変形応力を 示すが，Eの変形応力はそれらよりも小さいものとなってい る。ひずみが 0.6 を超える付近から, 試料の扁平化に伴う摩 擦力の増大によると考えられる変形応力の増大が，いずれの 試料においても認められる。

\section{2 集合組織}

\subsection{1 試料 $\mathrm{D}$ の組織と集合組織}

Fig. 6 (a)〜 (c) は試料Dについてひずみの増大に伴う集合 組織の変化を（0001）極点図により示したものである。圧縮 面を投影面とし，平均極密度 1 としてその倍数で極密度の分 布が示されている。変形前Fig. 3 (a) には極密度の中心部の みに平均極密度の 4 倍程度の極密度の集積が認められる。ひ ずみが 0.4 の段階で左右端部にも集積が現れ，ひずみが 1.0 に 達すると中心部での極密度が平均極密度 16 倍を超える水準 に達すると同時に, 左右端部の極密度も 8 倍程度まで増大す る。2 所の極密度集積位置の間には連続的な極密度の分布 はないが，中心部ならびに左右端部いずれにおいても左右方 向に極密度の集積の広がりが認められる。

$4 \mu \mathrm{m}$ 間隔で行ったEBSD測定をもとに描いた結晶粒組織図 がFig. 7 (a)，（b）である。結晶粒の圧縮面の方位が図中の逆 極点図に示された色の濃淡で表示されている。また，方位差 が $15^{\circ}$ 以上存在する場合に大角粒界が存在するとして黒い太 線が描いてある。結晶方位，大角粒界のこれらの表示方法は

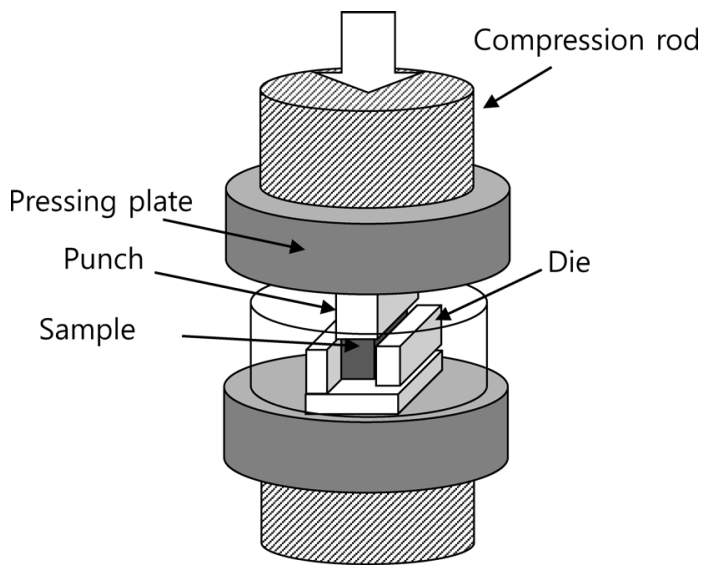

Fig. 4 Arrangement of the apparatus for plane strain compression test.
以後現れるすべての結晶粒組織図共通である。図の上下方位 が平面ひずみ圧縮変形における伸長方向であるが，結晶粒は その方向には伸長しておらず，粒界移動が生じていることが わかる。（0001）に近い方位の結晶粒が多いのは変形前と変 形後, 同様であるが, 両者の違いは結晶粒の形状である。変 形前の結晶粒は等軸形状のものが多いのに対し, 変形後の結 晶粒は，例えば図中に矢印で示したように，複数の結晶粒が 連結，すなわち粒界移動によって一方の結晶粒が他の結晶粒 全域まで広がったことを示す形状となっている。これは粒界 移動の駆動力が粒内転位密度の差に由来する蓄積エネルギー 差であることを示唆している。

\subsection{2 試料 $\mathrm{E} の$ 組織と集合組織}

Fig. 8 は試料Eについて Fig. 6 と同様に集合組織の発達過程

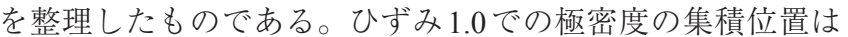
試料 D と類似して, 極点図中心部と左右端にある。変形前に はほとんど存在しなかった極点図中央部での極密度の集積が 平均極密度 4 倍に達すると同時に, 左右端部での極密度は平 均極密度の8倍を超えている。また中心部と左右端部の間に 連続的な極密度の分布が認められる。

Fig.9はひずみ 1.0 まで変形した後の結晶粒組織図である。 図中に矢印で示したようにFig. 7 と同じく，一方の結晶粒が 他方の結晶粒全体まで広がった形の結晶粒が観察される。

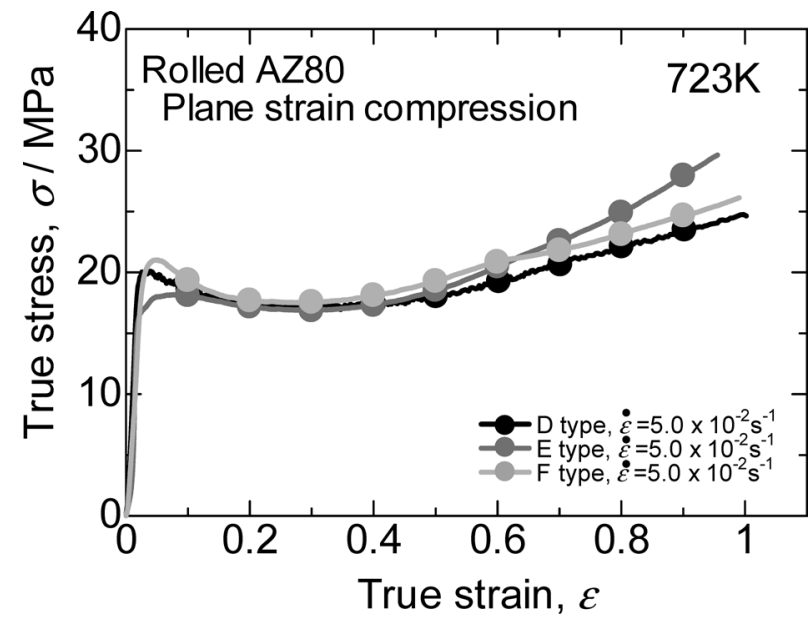

Fig. 5 True stress-true strain curves for the specimens of D, $\mathrm{E}$ and $\mathrm{F}$. (a)

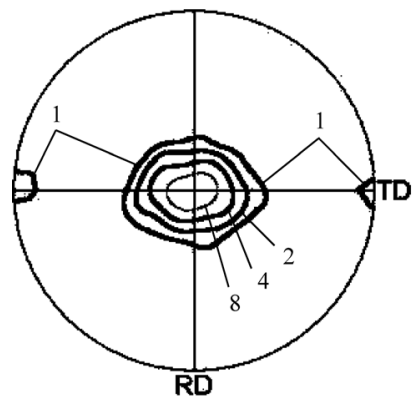

(b)

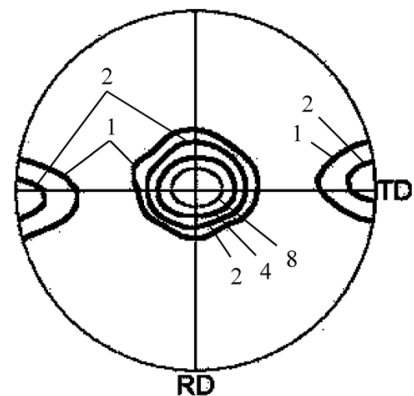

Levels:1, 2, 4, 8, 16

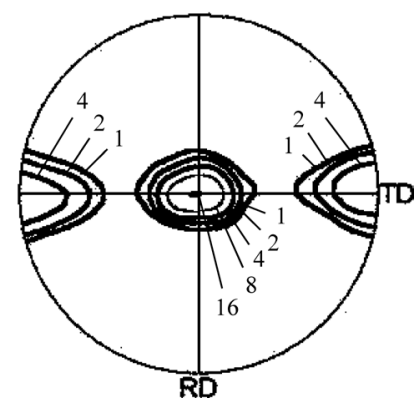

Fig. 6 (0001) pole figures showing the effect of strain on the texture of the specimen D. Absolute values of true strains of (a), (b) and (c) are 0.4, 0.7 and 1.0, respectively. 


\subsection{3 試料Fの組織と集合組織}

Fig. 10は試料Fについて, Fig. 6ならびにFig. 8 と同様の方 法で集合組織の発達過程を整理したものである。変形前には 上下端部にのみ極密度の集積が存在しているが，ひずみ 0.4 の変形で中心部に向かう極密度の分布の広がりが生まれてい る。ひずみが 1.0 になると上下と左右，そして中心部に極密 度の集積が形成される。Fig. 10 (c) に見られる極密度の最大 值は 8 倍を超えている。また, 結晶粒組織の特徵は, すでに Fig. 7 およびFig. 9 に示した結晶粒組織の特徵と同様であっ た。

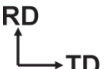

(a)

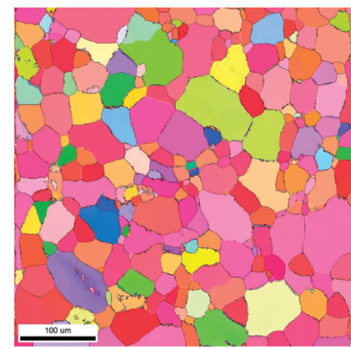

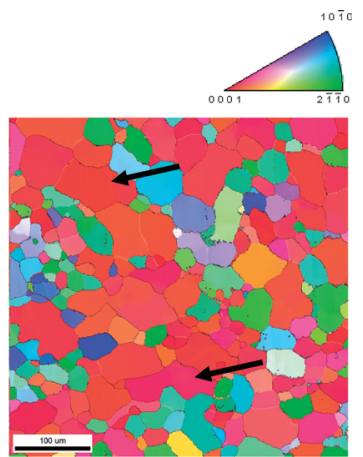

(b)
Fig. 7 Microstructure of specimen D observed by EBSD measurements (a) before deformation and (b) after deformation up to a strain of 1.0.
4. 考察

\section{1 （0001）方位結晶粒の形成}

前報では（1）集合組織の主成分〈10 10 0 が圧縮方向とな る試料 A，（2）平面ひずみ圧縮変形において変形が拘束され

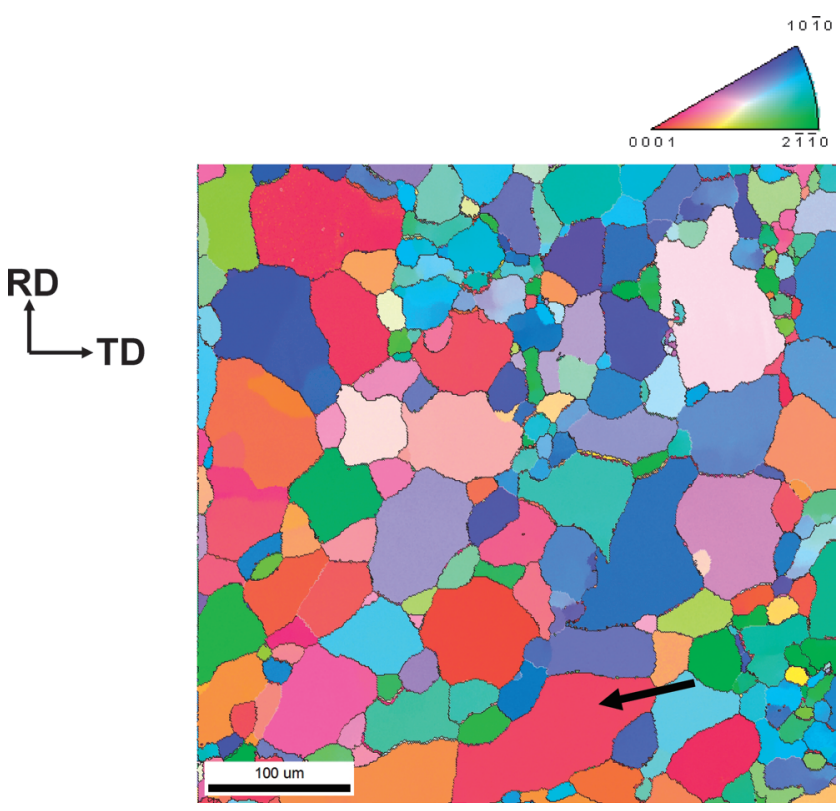

Fig. 9 Microstructure of specimen E observed by EBSD measurements after deformation up to a strain of 1.0. (a)

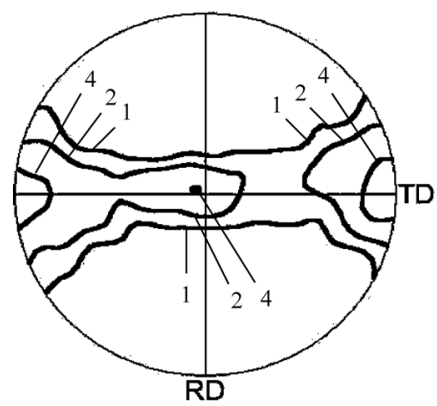

(b)

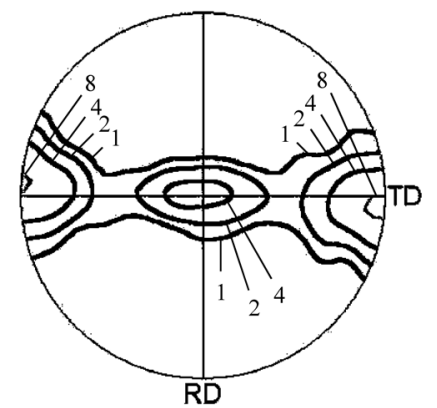

(c) Levels:1, 2, 4, 8

Fig. 8 (0001) pole figures showing the effect of strain on the texture of the specimen E. Absolute values of true strains of (a), (b) and (c) are $0.4,0.7$ and 1.0 , respectively.

(a)

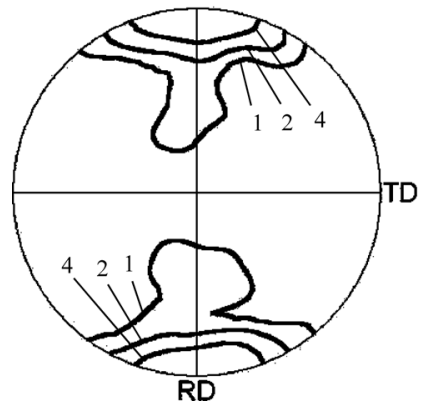

(b)

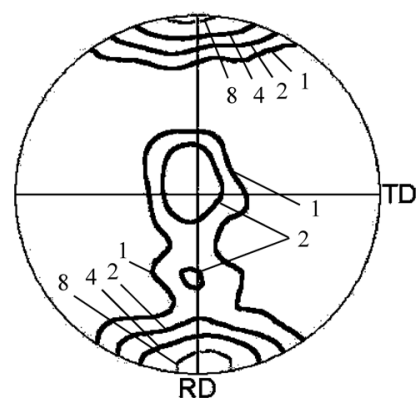

(c)

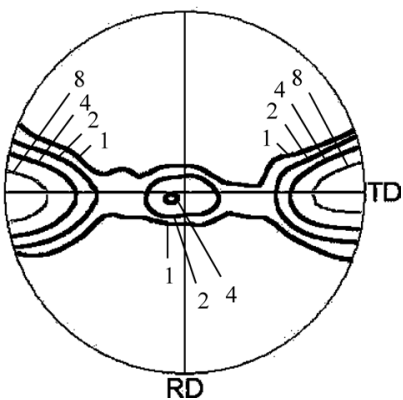


Table 1 The summary of six texture component for AZ80 magnesium alloy deformed $723 \mathrm{~K}, 5.0 \times 10^{-2} \mathrm{~s}^{-1}$ and strain up to -1.0 .

\begin{tabular}{|c|c|c|c|c|c|c|}
\hline & \multicolumn{2}{|c|}{$\mathrm{D}$} & \multicolumn{2}{|c|}{ E } & \multicolumn{2}{|c|}{$F$} \\
\hline & \multicolumn{2}{|c|}{$\varepsilon$} & \multicolumn{2}{|c|}{$\varepsilon$} & \multicolumn{2}{|c|}{$\varepsilon$} \\
\hline & 0 & -1.0 & 0 & -1.0 & 0 & -1.0 \\
\hline$\{0001\}\langle 10 \overline{1} 0\rangle$ & 0 & $\square$ & $\Delta$ & (2) & $\Delta$ & (a) \\
\hline$\{0001\}\langle 11 \overline{2} 0\rangle$ & $\bigcirc$ & (2) & $\Delta$ & $\Delta$ & $\Delta$ & (a) \\
\hline$\{10 \overline{1} 0\}\langle 0001\rangle$ & $\Delta$ & $\Delta$ & $\boldsymbol{\Delta}$ & $\Delta$ & $\bigcirc$ & 0 \\
\hline$\{10 \overline{1} 0\}\langle 11 \overline{2} 0\rangle$ & $\Delta$ & $\Delta$ & $\bigcirc$ & (2) & $\Delta$ & $\Delta$ \\
\hline$\{11 \overline{2} 0\}\langle 10 \overline{1} 0\rangle$ & $\Delta$ & () & $\bigcirc$ & $\bigcirc$ & $\triangle$ & $\triangle$ \\
\hline$\{11 \overline{2} 0\}\langle 0001\rangle$ & $\Delta$ & $\Delta$ & $\triangle$ & $\Delta$ & $\bigcirc$ & (a) \\
\hline
\end{tabular}

$\mathbf{\Delta}<2.0, \triangle<4.0, \bigcirc<8.0,(\mathrm{O}<16, \square>16$

る横方向が〈1010〉となる試料 B，（3）平面ひずみ圧縮変形 における伸長方向が $\langle 10 \overline{1} 0\rangle$ となる試料 Cの3 種について調 ベた。試料 $\mathrm{B}$ およびCでは変形開始前に，（0001）極点図に おいて平均極密度の 4 倍を超える極密度で底面集合組織成分 が存在していた。一方試料Aでは変形前には（0001）極点図 の中心部に平均極密度を上回る極密度の集積は存在していな かった。

本研究と同じ条件の $723 \mathrm{~K}, 5.0 \times 10^{-2} \mathrm{~s}^{-1}$ の変形では, A, B, Cすべての試料に底面集合組織成分が認められた。真ひずみ 1.0 での（0001）極点図の中心部での極密度はAでは 4 程度 であるのに対し，Bでは22，Cでは26であった。Bおよび C では変形前の極密度分布が徐々に移動する形で底面集合組織 が形成されるのに対し，Aでは極密度分布は不連続で，独立 して底面集合組織成分が現れることから，変形双晶の生成が 契機になったものと考えた。一方，BおよびCではすでに存 在していた底面方位の結晶粒が成長したと考えた。しかし， 底面方位を持つ結晶粒が変形前には存在せず，かつ平面ひず み圧縮変形下で双晶による底面方位粒の形成が困難な場合に も底面方位成分が形成されるか否かについてはこれらの初期 集合組織材の研究では明らかにはできなかった。変形前の底 面方位を持つ結晶粒の存在について本研究の試料 D, E, F を眺めると，Dでは高い極密度で変形前に存在している。ま た， Fにおいては平面ひずみ圧縮変形時に引張双晶が生成さ れると，前報の試料 $\mathrm{A}$ と同様に底面方位が形成されることに なる。しかし，試料Eにおいては，変形前には底面方位を持 つ結晶粒はほとんど存在せず，また変形双晶によって底面方 位を持つ結晶粒が生成される状況にもない。

しかし, Fig. 6, Fig. 7, Fig. 9 に見られるように, 変形前 の集合組織にかかわらず，変形後にはいずれも底面方位の発 達が認められる。（0001）極点図の中央部における極密度は, ひずみが1.0の段階で，Dが16倍強，Eが4倍強，Fで 8 倍強 となっている。試料 Eに対する Fig. 8, 試料 Fに対する Fig. 10 をみると, 既報の試料 B， Cでは初期集合組織に隠れて確 認できなかった変形による（0001）に向かう極密度分布の発

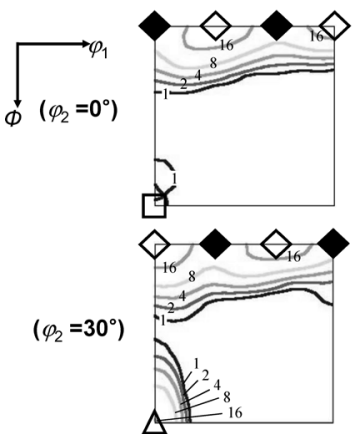

(a) (b)

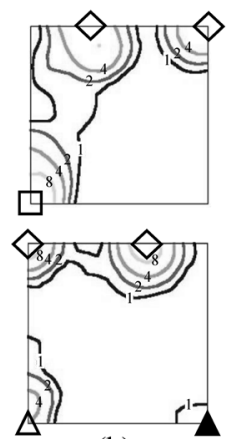

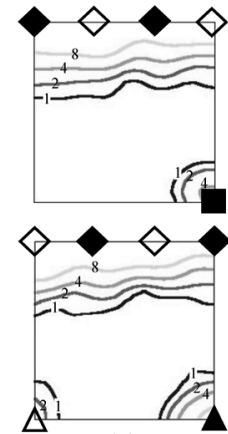

(c)
$\Delta\{0001\}<10 \overline{1} 0>\quad \forall\{0001\}<11 \overline{2} 0>\quad \square\{10 \overline{1} 0\}<11 \overline{2} 0>$ $\square\{10 \overline{1} 0\}<0001>\quad \Delta\{11 \overline{2} 0\}<10 \overline{0} 0>\quad \Delta\{11 \overline{2} 0\}<0001>$

Fig. $11 \varphi_{2}$ sections for specimens $(\mathrm{a}) \mathrm{D},(\mathrm{b}) \mathrm{E}$ and $(\mathrm{c}) \mathrm{F}$, after the deformation up to a true strain of 1.0.

達が認められる。このことは, 底面方位成分の結晶粒は, 他 方位の結晶粒を消費する（0001）方位結晶粒の成長だけでな く, 変形による結晶回転によっても形成される可能性を示唆 している。

\section{2 集合組織の方位成分}

Fig. 11は集合組織の方位成分を明らかにするために変形後 の試料について描いた $\varphi_{2}=0^{\circ}$ および $\varphi_{2}=30^{\circ}$ 断面である。ここ では $\left(\varphi_{1}, \Phi, \varphi_{2}\right)$ が $(0,0,0)$ の場合に $(0001)\langle 11 \overline{2} 0\rangle$ になる座 標系を用いている。試料Fでは（0001）（圧縮面）繊維集合 組織と $\{11 \overline{2} 0\}\langle 10 \overline{1} 0\rangle, \quad\{11 \overline{2} 0\}\langle 0001\rangle$ さらに $\{10 \overline{1} 0\}\langle 0001\rangle$ に方位密度の集積がある。一方試料DおよびEでは（0001） $\langle 10 \overline{1} 0\rangle$ および $\{11 \overline{2} 0\}\langle 10 \overline{1} 0\rangle$ に高い方位密度の集積が認め られる。見出された方位成分の方位密度を, 変形前後につい て比較した結果がTable 1である。本研究の試料D, E, Fで 計 6 種類の方位成分が見出されたが，これらは，既報の他の 3 種類の試料で見出された方位と同一で，新たな方位成分は 見出されない。この表では, 方位密度を5段階に分類し, 記 号で表示してある。表から $(0001)\langle 10 \overline{1} 0\rangle$ は変形前の集合組 織によらず変形によって発達すること, そして方位密度は最 低でも平均方位密度の8倍以上であることがわかる。すなわ ち, 高温平面ひずみ圧縮変形について他者が報告してい る $(0001)\langle 11 \overline{2} 0\rangle^{9), 10)}$ の顕著な発達はこの変形条件では認め られない。また， $(0001)\langle 10 \overline{1} 0\rangle$ を除くと，3種類の試料す べてに共通して高い方位密度で現れる結晶方位は存在しな い。しかし，初期集合組織に依存して，変形により発達する 方位成分がある。例えば試料 Fにおける $\{11 \overline{2} 0\}\langle 0001\rangle$ であ る。この方位は試料 D, Eでは変形後にはほとんど認められ ないが, 試料Fでは8倍を超える高い方位密度の成分となる。 試料 $\mathrm{F}$ は変形前に伸長方向に〈0001〉が頻度高く配向した繊 維集合組織が存在している。 $\{11 \overline{2} 0\}\langle 0001\rangle$ は前報の試料 B でも発達した。試料 $\mathrm{B}$ は横方向を〈10 10$\rangle$ とする繊維集合組 織をもつ試料である。試料 $\mathrm{B}$ と Fに共通する結晶方位は $\{11 \overline{2} 0\}\langle 0001\rangle$ であり，ここで見られた $\{11 \overline{2} 0\}\langle 0001\rangle$ の発 達は，この結晶方位の結晶粒が変形中に他方位の結晶粒を消 費して成長したことを示唆している。同様に既報の結果と合 せ考えると, 変形前に存在していた結晶粒の成長によって高 い方位密度が形成されたと思われる方位に試料 $\mathrm{E} て ゙$ 発達する $\{10 \overline{1} 0\}\langle 11 \overline{2} 0\rangle$ がある。この方位成分は既報の試料 Aでも発 達が認められた。Aは変形前に圧縮方向に〈1010〉が配向し 
た繊維集合組織を持つ試料であった。一方，試料Eには変形 前に横方向に〈0001〉が配向した繊維集合組織が存在してい る。両者に共通する結晶方位が $\{10 \overline{1} 0\}\langle 11 \overline{2} 0\rangle$ となる。これ

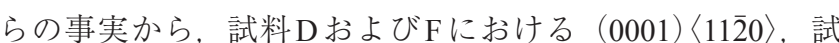
料Dで発達が認められる $\{11 \overline{2} 0\}\langle 10 \overline{1} 0\rangle$ なども変形前に存在 していた結晶粒の成長によるものではないかと考えられる。 また，すでに指摘したように，これらの方位成分は変形に対 して安定であり，それゆえ変形後に観察されたと考えられ る。

\section{3 底面集合組織形成の制御}

前報 ${ }^{6)}$ の試料 $\mathrm{A} \sim \mathrm{C}$ そして本報の試料 $\mathrm{D} \sim \mathrm{F}$ の計 6 種類の初 期方位の異なる場合について，温度ならびにひずみ速度を同 一にして平面ひずみ圧縮変形を行い，集合組織の形成挙動を 調べた。その結果， $(0001)\langle 10 \overline{1} 0\rangle$ が例外なく形成されるこ とが判明した。この結晶方位は, 変形に対して安定なだけで なく，複数の結晶粒がつながった形の結晶粒が観察されるこ となどから，変形中に他方位結晶粒を消費して成長できる方 位でもあると考えられる。そして，この方位は結晶回転に よっても生まれる可能性があることが本研究により見出され た。底面集合組織は，その後の成形には好適でないため，そ の発達を抑制することが望まれている。しかし，多様な初期 集合組織から出発した本研究ならびに前報の結果から, 本研 究の変形条件では，底面集合組織の発達の抑制は困難である ことがわかった。底面方位粒が変形双晶やすべり変形によっ

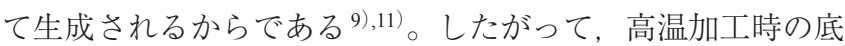
面集合組織の発達を抑制するには，複数活動すると考えられ るすべり系の相対的な活動比や変形双晶の活動度を変えるこ とが不可欠であり，温度，ひずみ速度を多様に変えて集合組 織の形成挙動を調べることが必要である。著者らはすでにこ の実験を進めているが，報告は別に譲ることとした。

\section{5. 結言}

高温変形によりAZ80合金に形成される集合組織の形成機 構を明らかにするため，熱間圧延を行って初期集合組織を付 与した板材から，集合組織の主成分の異なる試料を 3 種類作

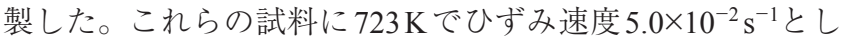
て平面ひずみ圧縮変形を施し, 組織観察, 集合組織解析を
行った。得られた結果を, 押出加工によって集合組織を付与 した棒材から作製した試料について前報の結果と合せて検討 した。その結果, 以下の結論を得た。

（1）いずれの試料においても底面集合組織が形成された。 EBSDによる組織観察では，（0001）（圧縮面）方位結晶粒に よる隣接結晶粒の消費が認められ, 底面集合組織の形成が粒 界移動によることが判明した。

（2）（0001）方位結晶粒は双晶のほか，変形による結晶回 転によっても生成される可能性がある。

(3) 変形後の集合組織には計 6 種類の結晶方位成分が 存在する。変形前の集合組織によらず変形されるのは (0001) 〈1010〉のみであった。

(4) $(0001)\langle 10 \overline{1} 0\rangle$ 以外の集合組織成分は, 変形前の集合 組織に依存して表れる。これらの成分は, 変形前に存在して いた結晶方位であり，かつ変形に対して安定なものであると 考えられる。

\section{謝 辞}

本研究の研究経費の一部は軽金属奨学会の支援によるもの である。ここに記して感謝する。実験および実験結果の解析 に注力してくれた横浜国立大学学生 吉田久志君に感謝す る。

\section{参 考 文 献}

1) K. Okayasu, H. Sakakibara and H. Fukutomi: Mater. Process. Texture: Ceramic Trans., 200 (2008), 679-685.

2）岡安和人, 竹腰弘毅, 榊原将之, 福富洋志：日本金属学会誌, 73 (2009), 58-63.

3) K. Okayasu, S. Takahata and H. Fukutomi: Mater. Sci. Forum, 495497 (2012), 336-339.

4）小貫祐介, 岡安和人, 福富洋志：鉄と鋼， 98 (2012), 27-33

5）堀内 良, 大塚正久：日本金属学会誌，35(1971), 406-415,

6）金珍旭，岡安和人，福富洋志：軽金属, 62 (2012), 54-59.

7) A. Galiyev, R. Kaibyshev and G. Gottstein: Acta. Mater., 49 (2001), 1199-1207.

8) M. Dahms and H. J. Bunge: J. Appl. Crystallogr., 22 (1989), 439-447.

9) R. Gehrmann, M. M. Frommert and G. Gottstein: Mater. Sci. Eng. A 395 (2005), 338-349.

10) G. Gottstein, T. Al-Samman: Mater. Sci. Forum, 495-497 (2005), 623-632.

11) P. Van Houtte, Acta Metall. 26 (1978), 591-604. 